\title{
Perbandingan Variasi Konsentrasi Pupuk Organik Cair dari Limbah Ikan Terhadap Pertumbuhan Tanaman Cabai Merah (Capsicum annum L.)
}

\author{
Fatimatuz Zahroh'1, Kusrinah², Siti Mukhlishoh Setyawati ${ }^{3}$ \\ Prodi Pendidikan Biologi, Fakultas Sains dan Teknologi, UIN Walisongo Semarang \\ Email: 1azzahrajm@yahoo.co.id, 2kusrinah@walisongo.ac.id, ${ }^{3}$ siti.mukhlishoh@walisongo.ac.id
}

\begin{abstract}
Abstrak
Limbah ikan merupakan salah satu limbah yang belum dimanfaatkan secara maksimal. Potensi limbah ikan berupa jeroan dapat dimanfaatkan sebagai pupuk organik cair karena masih mengandung unsur hara yang dibutuhkan tanaman. Pupuk organik cair merupakan salah satu pupuk yang dapat digunakan untuk tanaman holtikultura seperti tanaman cabai merah (Capsicum annum L.). Penelitian ini bertujuan untuk mengetahui pengaruh perbedaan pemberian variasi konsentrasi pupuk organik cair dari limbah ikan terhadap pertumbuhan tanaman cabai merah (Capsicum annum L.). Jenis penelitian ini adalah penelitian kuantitatif. Pendekatan penelitian yang digunakan adalah eksperimental laboratorium dengan menggunakan Rancangan Acak Lengkap yang terdiri dari 5 perlakuan 4 ulangan sehingga ada 20 unit eksperimen dan ditempatkan secara acak yaitu pupuk 0\% (P1), pupuk 3,5\% (P2), pupuk 4\% (P3), pupuk 4,5\% (P4), dan pupuk 5\% (P5). Pengamatan dilakukan terhadap tiga parameter pertumbuhan yaitu jumlah daun, diameter batang, dan tinggi tanaman. Teknis analisis data menggunakan One-way ANOVA dengan taraf signifikansi 5\% dan uji lanjutan Duncan. Hasil uji One-way ANOVA pada pertumbuhan jumlah daun tanaman cabai merah adalah $F_{\text {hitung }}$ sebesar 6,770 dan $F_{\text {tabel }}$ yaitu 3,06 ( $\left.F_{\text {hitung }}>F_{\text {tabel }}\right)$. Hasil uji One-way ANOVA pada pertumbuhan tinggi batang adalah $\mathrm{F}_{\text {hitung }}$ sebesar 5,267 dan $\mathrm{F}_{\text {tabel }}$ yaitu $3,06\left(\mathrm{~F}_{\text {hitung }}\right.$ $>\mathrm{F}_{\text {tabel }}$. Hasil uji One-way ANOVA pada pertumbuhan diameter batang tanaman cabai merah adalah

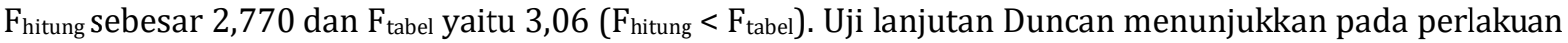
konsentrasi 4,5\% (P4) menunjukkan perbedaan yang paling signifikan terhadap pertumbuhan jumlah daun dan tinggi batang tanaman cabai merah.
\end{abstract}

Kata Kunci: pupuk organik cair, limbah ikan, pertumbuhan tanaman, cabai merah.

\section{Pendahuluan}

Perkembangan industri perikanan saat ini makin pesat, karena didukung oleh besarnya potensi sumberdaya perikanan di Indonesia. Industri pengolahan maupun pemanfaatan ikan oleh rumah tangga, banyak bagian ikan yang dibuang seperti kepala, ekor sirip, tulang dan jeroan yang pada akhirnya menyebabkan limbah. Limbah perikanan ini semakin meningkat karena adanya peningkatan konsumsi manusia untuk sumberdaya perikanan sehingga berbanding lurus dengan banyaknya limbah perikanan yang dihasilkan. Limbah perikanan yang dihasilkan berupa kulit, tulang, kepala, ekor dan jeroan. Jeroan terdiri dari lambung, usus, hati, kantung empedu, pankreas, gonad, limpa, dan ginjal. Sukarsa (1978) dalam Kurniawati (2004) menyebutkan bahwa jeroan ikan mengandung protein 36-57\%; serat kasar 0,052,38\%; kadar air 24-63\%; kadar abu 5-17\%; kadar Ca 0,9-5\%, serta kadar P 1-1,9\%.

Limbah ikan di Indonesia belum dimanfaatkan secara maksimal. Kurangnya pengetahuan masyarakat pada umumnya tentang pemanfaatan limbah ikan dan belum adanya penerapan teknologi dalam pengelolaan limbah ikan menjadi kendala dalam pemanfatan limbah ikan. Potensi limbah ikan yang sedemikian besar 
sangat disayangkan sekali apabila hanya berakhir di tempat pembuangan sampah yang tidak hanya akan menimbulkan bau busuk yang menyengat tetapi juga dapat mengganggu lingkungan serta pemukiman penduduk yang rumahnya berdekatan dari tempat pembuangan sampah tersebut. Limbah tersebut berpotensi memicu timbulnya pencemaran udara dan gangguan kesehatan terhadap masyarakat sekitar.

Pemanfaatan limbah ikan secara sederhana sudah dilakukan diantaranya dimanfaatkan sebagai tepung ikan, minyak ikan, galantine, bakso dan pakan ternak baik secara langsung maupun dalam bentuk pellet, seperti pada home industry pengasapan ikan nila di Desa Gebyok Gunung Pati Semarang. Pendekatan konsep zero waste atau meminimalkan hasil samping/ limbah sehingga lebih bernilai tambah merupakan salah satu konsep dengan cara memanfaatkan limbah perikanan yang belum dimanfaatkan secara maksimal menjadi pupuk organik cair.

Ikan sisa atau ikan-ikan yang terbuang ternyata masih dapat dimanfaatkan sebagai bahan baku pupuk organik lengkap, yakni pupuk yang memiliki kandungan unsur-unsur makronya terbatas (tidak mencukupi untuk kebutuhan tanaman) dan harus dilengkapi dengan penambahan unsur lainnya sehingga kandungan $\mathrm{N}$, $\mathrm{P}, \mathrm{K}$ nya sesuai yang dibutuhkan. Bentuk pupuk organik yang berupa cairan dapat mempermudah tanaman dalam menyerap unsur-unsur hara yang terkandung di dalamnya dibandingkan dengan pupuk lainnya yang berbentuk padat. Pupuk berbahan baku ikan selain sebagai sumber hara juga mampu menginduksi Actinomycetes spp. dan Rhizobacteria spp. Yang berperan dalam menghasilkan hormon tumbuh di sekitar perakaran tanaman. Hormon tumbuh yang dimaksud adalah hormon auksin, sitokinin dan giberelin.

Penggunaan pupuk organik diharapkan dapat memperbaiki kesuburan tanah sekaligus menyediakan unsur hara yang dibutuhkan oleh tanaman komoditas pertanian. Pupuk organik cair adalah salah satu jenis pupuk yang dapat digunakan untuk meningkatkan produktivitas komoditas pertanian. Pupuk organik cair mengandung unsur hara makro dan mikro esensial yang cukup tinggi seperti N, P, K, S, Ca, Mg, B, Mo, Cu, Fe, Mn, dan bahan organik.

Pupuk organik cair merupakan salah satu pupuk yang bisa digunakan untuk tanaman holtikultura. Tanaman holtikultura merupakan tanaman yang dibudidayakan oleh manusia. Salah satu tanaman holtikultura adalah cabai merah. Cabai merah (Capsicum annum L.) merupakan salah satu komoditas hortikultura yang penting. Banyaknya manfaat pada cabai yang dapat dipergunakan untuk berbagai keperluan, baik yang berhubungan dengan kegiatan rumah tangga maupun untuk keperluan lain seperti untuk bahan ramuan obat tradisional, bahan makanan dan minuman serta industri. Tanaman cabai memiliki kandungan gizi dan vitamin di antaranya, protein, lemak, karbohidrat, kalsium, vitamin A, B1 dan vitamin C.

Cabai merah merupakan komoditas sayuran yang memiliki nilai ekonomi tinggi dan banyak diusahakan oleh petani di dataran rendah sampai di dataran tinggi. Penanamannya dapat dilakukan di lahan sawah maupun lahan kering. Ada dua jenis cabai merah yang umum di budidayakan oleh petani Indonesia, yaitu cabai merah besar dan cabai merah keriting. Berdasarkan varietasnya, cabai digolongkan menjadi varietas hibrida dan non hibrida. Varietas Laris merupakan salah satu varietas non hibrida dari jenis cabe merah keriting lokal yang cocok ditanam pada dataran rendah. Desa Daren Kecamatan Nalumsari Kabupaten Jepara adalah daerah dataran rendah sehingga cocok untuk penanaman cabai merah keriting varietas Laris.

Penelitian yang pernah dilakukan oleh Pareng Rengi dan Sumarto yang berjudul Kajian Pemanfaatan Hasil Samping Perikanan untuk 
Pembuatan Pupuk Organik Cair tahun 2011, menyatakan bahwa pupuk cair yang dihasilkan dari limbah ikan nila memiliki karakteristik warna sedikit cerah sampai dengan warna gelap dan pekat. Pupuk cair yang dihasilkan dari limbah ikan patin memiliki karakteristik warna agak cerah, tidak pekat sampai dengan warna gelap, pekat dan sedikit berminyak. Pupuk cair yang dihasilkan dari limbah ikan kembung memiliki karakteristik warna cerah dan cemerlang, tidak pekat sampai dengan warna agak gelap dan pekat, tetapi tidak berminyak. Perlu adanya proses lebih lanjut yaitu proses pemurnian pupuk cair yang dihasilkan, perlakuan penghilangan komponen gas yang masih terdapat pada pupuk cair, dan perbandingan proses pencairan (pupuk cair dan tambahan air) sebelum dilakukan penerapan untuk tanaman. Penelitian mengenai pupuk organik cair dari limbah ikan memang sudah pernah dilakukan dengan komposisi yang berbedabeda, akan tetapi aplikasi terhadap tanaman cabai merah belum pernah dilakukan. Penelitian ini diharapkan mampu memberikan informasi bagi masyarakat pada umumnya bahwa limbah ikan dapat menjadi alternatif pupuk organik cair yang dapat dibuat sendiri terutama pada sektor pertanian sekaligus megatasi pencemaran lingkungan dengan memnfaatkan limbah yang sudah tidak terpakai.

\section{Metode}

Penelitian dilakukan di Desa Daren, Kecamatan Nalumsari, Kabupaten Jepara dimulai pada tanggal 18 September 2015-8 November 2015. Analisa kualitas unsur hara N, P, dan K dilakukan di Laboratorium Balai Pengkajian Teknologi Pertanian (BPTP) Jawa Tengah pada tanggal 3 November 2015. Limbah yang digunakan sebagai bahan penelitian adalah jeroan ikan nila dari home industry pengasapan ikan nila di Desa Gebyok Gunung Pati Semarang.

Alat yang digunakan adalah botol 1,5 L, ember plastik, sekop, kertas $\mathrm{pH}$ indikator universal, polybag ukuran 20x20 sebanyak 20 buah, 1 buah tray/nampan, timbangan, kertas label, 5 buah sprayer ukuran $100 \mathrm{ml}$, Soil tester, Termometer, Lux meter, gelas ukur $25 \mathrm{ml}$, gelas takar $500 \mathrm{ml}$, penggaris, benang, alat tulis dan kain. Bahan tambahan lain adalah 1000 gram dedak, $500 \mathrm{ml}$ air kelapa, 100 gram gula pasir, $3 \mathrm{~L}$ air sumur, dan aktivator EM4 sebanyak $100 \mathrm{ml}$.

Penelitian ini menggunakan Rancangan Acak Lengkap (RAL) yang terdiri dari 5 perlakuan 4 ulangan sehingga ada 20 unit eksperimen dan ditempatkan secara acak. Perlakuan yang dilakukan pada tanaman cabai merah dalam penelitian ini adalah P1= Perlakuan dengan konsentrasi pupuk limbah ikan 0 \% (Perlkuan Kontrol), P2 = Perlakuan dengan konsentrasi pupuk limbah ikan 3,5 \% (35 ml pupuk dalam 1000 ml larutan), P3 = Perlakuan dengan konsentrasi pupuk limbah ikan $4 \%$ (40 ml pupuk dalam $1000 \mathrm{ml}$ larutan), P4 = perlakuan dengan konsentrasi pupuk limbah ikan 4,5 \% (45 ml pupuk dalam $1000 \mathrm{ml}$ larutan), P5 = Perlakuan dengan konsentrasi pupuk limbah ikan $5 \%$ (50 ml pupuk dalam $1000 \mathrm{ml}$ larutan).

Penelitian dimulai dengan pengenceran EM4 dengan air menggunakan perbandingan 1/10 (10\%), yaitu EM4 $100 \mathrm{ml}, 100$ gram gula pasir dan air $1 \mathrm{~L}$ dimasukkan dalam botol berukuran 1,5 L kemudian didiamkan selama 5 hari dalam keadaan kedap udara. Proses ini bertujuan untuk mengembangbiakkan dan mengaktifkan mikroorganisme yang ada pada EM4 dari kondisi dorman, sehingga mikroorganisme dapat bekerja dengan efisien dan optimal pada saat dicampurkan ke dalam limbah ikan. Setelah 5 hari, EM4 dapat digunakan dengan indikasi tercium bau asam manis dengan pH EM aktif berkisar 3,5-3,7.

Proses pembuatan pupuk organik cair dimulai dengan memasukkan 1000 gram dedak, $500 \mathrm{ml}$ air kelapa, 500 gram limbah ikan nila, air sumur 2 L ke dalam ember plastik kemudian ditambahkan EM-4 yang telah diencerkan selama 5 hari, diaduk rata selama 15 menit kemudian ditutup rapat. Setiap 2 hari sekali dibuka agar 
mikroorganisme tidak mati dan diukur pHnya. Fermentasi berlangsung selama 30 hari. Setelah fermentasi 30 hari pupuk organik cair yang dihasilkan disaring menggunakan kain. Penambahan gula dan air kelapa berfungsi sebagai sumber glukosa yang akan digunakan oleh mikroorganisme pada EM4 sebagai sumber energinya. Dedak mengandung karbohidrat yang berfungsi sebagai sumber energi pada mikroorganisme. Dedak juga sebagai sumber karbon yang baik sehingga dapat mengoptimalkan pertumbuhan mikrobia efektif, sehingga proses fermentasi dapat berjalan secara optimal.

Pupuk organik cair yang telah jadi dilakukan pengujian kadar nitrogen total, fosfor dan kalium pada pupuk cair limbah ikan. Pengujian dilakukan di Laboratorium Balai Pengkajian Teknologi Pertanian (BPTP) Jawa Tengah. Pengujian nitrogen total menggunakan metode Kjeldahl yang dilkukan dengan tiga tahap, yaitu destruksi, destilasi dan titrasi.

Aplikasi pupuk organik cair pada tanaman cabai merah diawali dengan merendam biji cabai merah varietas Laris dengan air hangat selama 30 menit untuk mencegah penyakit tular benih sekaligus memecah masa dormansi (waktu istirahat) benih. Perendaman juga bertujuan untuk menyeleksi biji yang bagus dan tidak cacat dengan indikasi ketika direndam biji tidak terapung.

Media tumbuh yang digunakan adalah campuran tanah dan arang sekam dengan perbandingan 1:1 lalu dimasukan ke dalam nampan/tray. Biji yang telah direndam disemai dengan cara semai baris yaitu ditaburkan pada baris-baris persemaian pada media tanah dan arang sekam yang telah diolah, lalu ditutup dengan tanah tipis. Penyemaian dilakukan selama 14 hari atau telah memiliki 2 helai daun dan disiram setiap pagi dan sore hari. Setelah 4-7 hari dalam persemaian tumbuh benih yang mengeluarkan radikula atau calon akar siap ditanam. Penyiraman dengan air biasa dilakukan secukupnya setiap pagi hari agar tidak kekeringan atau terlalu lembab. Pemberian pupuk dilakukan 1 minggu setelah semaian pindah polibag sebanyak $100 \mathrm{ml}$ dengan cara disemprot pada tanah menggunakan sprayer. Pemberian pupuk selanjutnya dilakukan setiap 1 minggu sekali selama 4 minggu sekaligus dilakukan pengukuran. Pembatasan pemberian pupuk sampai 4 minggu dikarenakan penelitian dilakukan hanya pada fase pertumbuhan vegetatif tanaman.

Data yang diamati adalah jumlah daun, diameter batang $(\mathrm{cm})$ dan tingi batang $(\mathrm{cm})$. Data yang di ukur dan dikumpulkan dalam penelitian ini adalah sebagai berikut : jumlah daun dihitung pada helai daun yang telah membuka dengan sempurna. Diameter batang diukur dengan menggunakan tali rafia dan kemudian diukur pada penggaris dari pangkal batang. Tinggi batang diukur dengan menggunakan mistar, mulai dari pangkal batang (+ $1 \mathrm{~cm}$ di atas media) hingga titik tumbuh pucuk apikal. Pengukuran dimulai $+1 \mathrm{~cm}$ di atas media karena untuk menyeragamkan dan memudah-kan dalam proses pengukuran tinggi tanaman. Pengamatan dilakukan satu mingu sekali sampai tanaman berumur 1 bulan setelah tanam.

Semua data kuantitatif hasil dari pengamatan dianalisis secara statistik menggunakan analisis variansi (ANOVA) satu jalur dengan taraf signifikasi 5\%. Analisis statistik dilakukan dengan menggunakan program SPSS.

\section{Hasil dan Pembahasan}

Tabel rekapitulasi hasil variasi konsentrasi pupuk organik cair limbah ikan terhadap pertumbuhan tanaman cabai merah (Capsicum annum $\mathrm{L}$.) adalah sebagai berikut. 
Tabel 1. Rerata pemberian variasi konsentasi pupuk terhadap pertumbuhan tanaman cabai merah

\begin{tabular}{|l|c|c|c|}
\hline \multirow{2}{*}{ Perlakuan } & \multicolumn{3}{|c|}{ Rerata Pertumbuhan } \\
\cline { 2 - 4 } & Jumlah Daun (Helai) & Diameter Batang $(\mathrm{cm})$ & Tinggi Batang (cm) \\
\hline P1 & 13 & 20,2 & 19,73 \\
\hline P2 & 14,25 & 21.9 & 24,46 \\
\hline P3 & 17 & 24,1 & 25,1 \\
\hline P4 & 17,75 & 24,5 & 31,4 \\
\hline P5 & 17 & 24,2 & 30,5 \\
\hline
\end{tabular}

1. Jumlah Daun

Pertambahan jumlah daun tiap tanaman cabai merah ( Capsicum annum L.) diperoleh hasil analisis varian (ANOVA) pada tabel berikut.

\section{ANOVA}

\begin{tabular}{|l|r|r|r|r|r|}
\cline { 2 - 6 } jumlah daun & & & & & \\
\hline & \multicolumn{1}{|c|}{$\begin{array}{c}\text { Sum of } \\
\text { Squares }\end{array}$} & Df & $\begin{array}{c}\text { Mean } \\
\text { Square }\end{array}$ & F & Sig. \\
\hline $\begin{array}{l}\text { Between } \\
\text { Groups }\end{array}$ & 67.700 & 4 & 16.925 & 6.770 & .003 \\
Within Groups & 37.500 & 15 & 2.500 & & \\
Total & 105.200 & 19 & & & \\
\hline
\end{tabular}

2. Diameter Batang

Hasil analisis ANOVA terhadap pertumbuhan diameter batang tanaman cabai merah (Capsicum annum L.) yang diukur dalam satuan centimeter $(\mathrm{cm})$ diperoleh hasil ANOVA pada tabel berikut.

\section{ANOVA}

\begin{tabular}{|l|r|r|r|r|r|}
\cline { 2 - 6 } \multicolumn{1}{l|}{ diameter batang } & & & & & \\
\hline & \multicolumn{1}{|c|}{ Sum of } & & Mean & & \\
& Squares & Df & Square & \multicolumn{1}{c|}{ F } & \multicolumn{1}{c|}{ Sig. } \\
\hline Between Groups & 3.607 & 4 & .902 & 2.770 & .066 \\
Within Groups & 4.882 & 15 & .326 & & \\
Total & 8.490 & 19 & & & \\
\hline
\end{tabular}

\section{Tinggi Batang}

Hasil analisis ANOVA terhadap pertumbuhan tinggi batang tanaman cabai merah (Capsicum annum L.) yang diukur dalam satuan centimeter $(\mathrm{cm})$ diperoleh hasil ANOVA pada tabel berikut:

\section{ANOVA}

\begin{tabular}{|c|c|c|c|c|c|}
\hline \multicolumn{6}{|c|}{ tinggi batang } \\
\hline & $\begin{array}{c}\text { Sum of } \\
\text { Squares }\end{array}$ & Df & Mean Square & $\mathrm{F}$ & Sig. \\
\hline $\begin{array}{l}\text { Between } \\
\text { Groups }\end{array}$ & 366.533 & 4 & 91.633 & 5.267 & .007 \\
\hline $\begin{array}{l}\text { Within } \\
\text { Groups }\end{array}$ & 260.955 & 15 & 17.397 & & \\
\hline Total & 627.488 & 19 & & & \\
\hline
\end{tabular}


Hasil uji ANOVA menunjukkan bahwa perbandingan variasi konsentrasi pupuk organik cair limbah ikan memberikan pengaruh terhadap pertumbuhan tanaman cabai merah. Perlakuan pupuk konsentrasi 4,5\% (P4) memberikan pengaruh yang paling signifikan terhadap jumlah daun dan tinggi batang tanaman cabai merah. Pada pertumbuhan diameter batang konsentrasi 4,5\% (P4) juga memberikan pengaruh dan hasil tertinggi meskipun tidak signifikan. Konsentrasi 4,5 \% (P4) merupakan konsentrasi optimal terhadap pertumbuhan jumlah daun dan tinggi batang tanaman cabai merah. Perlakuan variasi konsentrasi pada pertumbuhan diameter batang tanaman cabai merah juga memberikan pengaruh tetapi tidak signifikan.

Ketersediaan nitrogen yang terserap oleh tanaman dapat dipenuhi dari proses fermentasi bahan baku yaitu limbah ikan, air kelapa dan dedak. Dengan demikian konsentrasi optimal pemberian pupuk organik cair dari limbah ikan pada tanaman cabai merah adalah $4,5 \%$.

Konsentrasi optimal tersebut didukung oleh kandungan dan keterserapan nutrisi dari pupuk organik limbah ikan terhadap unsur N,P,K. Hasil analisis unsur N, P, K yang dilakukan menunjukkan bahwa pada pupuk organik cair dari limbah ikan mengandung $\mathrm{N}$-total sebanyak $0,30 \%$, Fosfor dalam bentuk $\mathrm{P}_{2} \mathrm{O}_{5}$ sebanyak 0,65 \% dan Kalium dalam bentuk $\mathrm{K}_{2} \mathrm{O}$ sebanyak $0,17 \%$. Unsur N,P,K ini tidak terlalu tinggi jika disesuaikan dengan standar mutu pupuk komersil oleh Permentan yaitu Peraturan Menteri Pertanian Nomor 70/Permentan/SR.140/10/2011 menyebutkan bahwa standar mutu pupuk organik cair adalah sebesar $3-6 \%$.

Pertumbuhan yang baik bagi tanaman cabai merah adalah konsentrasi 4,5\% dapat didukung pula oleh ketersediaan makronutrien lainnya, seperti karbon, oksigen, hidrogen, nitrogen, fosfor, kalium, kalsium, dan sulfur yang dibutuhkan untuk siklus hidup tanaman dan menghasilkan generasi yang lain. Tanaman cabai merah seperti pada umumnya tanaman lain akan sehat jika unsur hara tersebut terpenuhi meskipun secara perhitungan besarnya diameter batang secara statistik tidak signifikan.

Makronutrien dapat tersedia pada proses fermentasi bahan pupuk yang mencakup limbah ikan, dedak dan air kelapa yang diaktivasi oleh mikroba dari EM-4.

Bahan pembuatan pupuk adalah limbah perikanan berupa jeroan. Jeroan terdiri dari lambung, usus, hati, kantung empedu, pankreas, gonad, limpa, dan ginjal. Sukarsa (1978) dalam Kurniawati (2004) menyebutkan bahwa jeroan ikan mengandung protein 36-57\%; serat kasar 0,052,38\%; kadar air 24-63\%; kadar abu 5-17\%; kadar Ca 0,9-5\%, serta kadar P 1-1,9\%.

Bahan tambahan lain adalah dedak padi. National Research Council (1994) menyebutkan bahwa dedak padi mengandung energi metabolis sebesar $2980 \mathrm{kkal} / \mathrm{kg}$, protein kasar 12,9\%, lemak $13 \%$, serat kasar $11,4 \%$, Ca $0,07 \%$, P tersedia 0,22\%, Mg 0,95\% serta kadar air 9\%. Dedak padi mengandung karbohidrat yang berfungsi sebagai sumber energi pada mikroorganisme. Dedak juga sebagai sumber karbon yang baik untuk mengoptimalkan pertumbuhan mikrobia efektif, sehingga proses fermentasi dapat berjalan secara optimal.

Dedak padi yang difermentasikan dengan EM4 mampu meningkatkan kandungan protein kasar. Peningkatan ini disebabkan oleh aktifitas enzim yang dihasilkan oleh mikroba yang terdapat dalam larutan EM4, seperti selulase yang dapat melepaskan protein yang terikat pada lignin.

Larutan EM4 juga terdapat bakteri fotosintetik yang mampu menghasilkan asam amino sehingga kandungan protein kasar pada dedak padi juga meningkat kemampuan ragi (yeast) yang terdapat pada EM4 untuk mengubah nitrogen bukan protein menjadi protein. 
Air kelapa merupakan bahan tambahan juga yang digunakan dalam pembuatan pupuk. Hasil analisis kandungan kimia air kelapa yang telah dilakukan oleh Natalini Nova Kristina dan Siti Fatimah Syahid menunjukkan bahwa komposisi ZPT kinetin (sitokinin) dalam air kelapa muda adalah 273,62 mg/l dan zeatin 290,47 mg/l, sedangkan kandungan IAA (auksin) adalah 198,55 mg/l. Tingginya kandungan sitokinin maupun auksin terjadi karena ZPT tersebut diproduksi dalam jaringan meristematik yang aktif membelah.

Pembuatan pupuk organik cair dilakukan melalui proses fermentasi. Fermentasi merupakan penguraian unsur organik kompleks terutama karbohidrat untuk menghasilkan energi melalui reaksi enzim yang dihasilkan oleh mikroorganisme, yang biasanya terjadi dalam keadaan anaerob dan diiringi dengan pembebasan gas, hal ini bertujuan untuk menekan pertumbuhan patogen agar proses degradasi berjalan dengan baik. Proses fermentasi menghasilkan metabolit mikroba primer dan sekunder. Metabolit primer contohnya etanol, asam sitrat, polisakarida, aseton, butanol dan vitamin. Metabolit sekunder contohnya antibiotik dan pemacu pertumbuhan sehingga mampu mempengaruhi kadar unsur pada pupuk.

EM4 mengandung spesies terpilih dari mikroorganisme utamanya yang bersifat fermentasi, yaitu bakteri asam laktat (Lactobacillus sp.), ragi (yeast), bakteri fotosintetik (Rhodopseudomonas sp.), dan Actinomycetes. EM4 yang merupakan bioaktivator dalam pembuatan pupuk organik limbah ikan mengandung mikroba yang membantu proses fermentasi yang membantu proses penyederhanaan unsur organik kompleks dari bahan yang digunakan. Hasilnya pupuk organik cair limbah ikan mempunyai keterserapan yang tinggi terhadap pertumbuhan tanaman cabai merah.

\section{Kesimpulan}

Perbandingan variasi konsentrasi pupuk organik limbah ikan memberikan pengaruh yang signifikan terhadap pertumbuhan jumlah daun dan tinggi batang tanaman cabai merah (Capsicum annum L.) dan memberikan pengaruh tetapi tidak signifikan terhadap pertumbuhan diameter batang tanaman cabai merah. Hasil uji One-way ANOVA pada pertumbuhan jumlah daun tanaman cabai

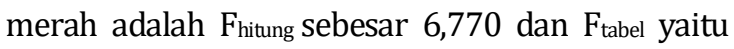
3,06 (F $\mathrm{F}_{\text {hitung }}>\mathrm{F}_{\text {tabel}}$ ). Hasil uji One-way ANOVA pada pertumbuhan tinggi batang adalah $F_{\text {hitung sebesar }}$ 5,267 dan $\mathrm{F}_{\text {tabel }}$ yaitu 3,06 ( $\mathrm{F}_{\text {hitung }}>\mathrm{F}_{\text {tabel }}$ ). Hasil uji One-way ANOVA pada pertumbuhan diameter batang tanaman cabai merah adalah $F_{\text {hitung sebesar }}$

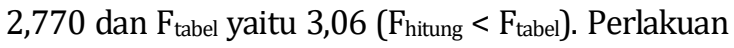
optimal dari perbandingan variasi konsentrasi pupuk organik cair limbah ikan terhadap pertumbuhan jumlah daun dan tinggi batang tanaman cabai merah terdapat pada konsentrasi 4,5\% (P4).

\section{Daftar Pustaka}

Campbell, Neil A. dan Jane B. Reece. 2012. Biologi Edisi 8 jilid 2 terj. Pearson Benjamin Cummings.

Cesaria, Rizki Yunia, dkk. Pengaruh Penggunaan Starter Terhadap Kualitas Fermentasi Limbah Cair Tapioka Sebagai Alternatif Pupuk Cair, Jurnal Sumberdaya Alam dan Lingkungan.

Devananta, Ari Akbar. 2013. Potensi Limbah Ikan sebagai Energi Alternatif yang Menjanjikan. Dalam http://berandainovasi.com/potensilimbah-ikan-sebagai-energi-alternatif-yangmenjanjikan/ diakses tanggal 27 Agustus 2015.

Ditjen Perikanan Budidaya, Artikel.dkp.go.id.

Dwicaksono et al. 2013. Pengaruh Penambahan Effective Microorganisms pada Limbah Cair Industri Perikanan Terhadap Kualitas Pupuk Cair Organik. Jurnal Sumberdaya Alam \& Lingkungan, 7-11.

El-Tarabily, K.A., A.H. Nassar, E.S. Giles, J. Hardy, and K. Sivasithamparam. 2004. Fish emulsion as a food base for rhizobacteria promoting growth of radish (Raphanus sativus L. var. sativus) in a sandy soil. Jurnal Plant and Soil, Vol. 252 (2): 397-411. 
Hidayat, Muhammad Nur, dkk. Rekayasa Komposisi Kimia Dedak Padi Dan Aplikasinya Sebagai Ransum Ayam Buras,tt, Artikel. Faculty of Science and Technology Universitas Islam Negeri Alaudin. Makasar.

Ilyas. 2014. Pupuk Organik Cair. Paper. Universitas Mulawarman. Samarinda.

Kristina, Natalini Nova, dkk. 2012. Pengaruh Air Kelapa Terhadap Multiplikasi Tunas In Vitro. Jurnal Littri, Vol. 18 No. 3.

Moekasan, Tonny K. Dkk. 2014. Panduan Praktis Budidaya Cabai Merah Beerdasarkan Konsepsi Pengendalian Hama Terpadu (PHT). PT. Penebar Swadaya. Jakarta.

M.S, Ayyatullah. 2011. Pemanfaatan Limbah Pengalengan Ikan Tuna Sebagai Hidrolisat Protein Serta Aplikasinya dalam Olahan Produk Pangan. Dalam http://zonasepta.com/, diakses tanggal 27 Agustus 2015.
Perundangan.pertanian.go.id/admin/file/Permenta n-70-11.pdf, diakses tanggal 21 Agustus 2015.

Rengi, Pareng dan Sumarto. 2011. Kajian Teknologi Pemanfaatan Hasil Samping Perikanan Untuk Pembuatan Pupuk Cair Organik. Jurnal Pusat Penelitian Lingkungan Hidup Universitas Riau.

S, Alex. 2012. Sukses Mengolah Sampah Organik Menjadi Pupuk Organik. Pustaka Baru Press. Yogyakarta.

Setyaningrum, Lucia Suci. 2008. Optimasi Fermentasi. Artikel: FMIPA UI.

Suryati, Teti. 2014. Bebas Sampah dari Rumah, PT. Agro Media Pustaka. Jakarta.

Yulianti, Evi. 2012. Peningkatan Kualitas Dedak Padi Melalui Suplementasi Berbagai Level Enzim Thermophytase Dan Suhu Pembuatan Pellet Sebagai Pakan Broiler. Artikel. Program Studi Ilmu Peternakan, Program Pascasarjana, Universitas Andalas. 